\title{
A New Genus of Holoparasitic Orobanchaceae from Mexico
}

\author{
George Yatskievych \\ Missouri Botanical Garden, P.O. Box 299, St. Louis, Missouri 63166-0299, U.S.A. \\ george.yatskievych@mobot.org
}

José Luis Contreras Jiménez

Herbario y Jardín Botánico, Benemérita Universidad Autónoma de Puebla, Edif. 76 Unidad de Ciencias C.U., Av. San Claudio s/n Col. San Manuel, 72590 Puebla, Puebla, México.

jlcontre@siu.buap.mx

Abstract. We describe here a novel achlorophyllous parasite on the roots of Hedyosmum mexicanum C. Cordemoy (Chloranthaceae) as a new genus and species, Eremitilla mexicana Yatskievych \& J. L. Contreras. The new taxon is currently thought to be endemic to the state of Guerrero, Mexico. It is best classified in the Orobanchaceae, but differs from other members of the family in having 5-ribbed, muricate ovaries containing five parietal placentae, as well as unusual stamens in which the anther is partially embedded in an expanded filament apex. Within the Orobanchaceae, the new taxon is probably related to a group that contains the other American holoparasitic genera. Morphologically, Eremitilla Yatskievych \& J. L. Contreras displays a number of autapomorphies, but few identifiable synapomorphies. This presumed relictual taxon presently is known only from a restricted habitat and a very small geographic range, and thus is of conservation concern.

Key words: Chloranthaceae, Eremitilla, Guerrero, Hedyosmum, IUCN Red List, Mexico, Orobanchaceae, parasitic plant.

In June 1985, during fieldwork in Guerrero, Mexico, New York Botanical Garden Curator Wayt Thomas stumbled upon a single inflorescence of an unusual achlorophyllous plant. He pressed a specimen and later sent this to Lawrence Heckard at the University of California, a specialist on the taxonomy of the parasitic plant family, Orobanchaceae. The late Dr. Heckard could not place the specimen; he concluded that the plant probably was not a member of the Orobanchaceae and suggested instead that it might represent an unnamed member of the mycoheterotrophic Monotropaceae (now considered a subfamily of the Ericaceae). For the next two decades, the specimen remained an undetermined entry in Dr. Thomas's field notebook.

In 2005, Thomas showed a photograph of the plant to Gerald Schneeweis of the University of Vienna, who has been conducting molecular phylogenetic studies of the Orobanchaceae. Through the courtesy of Schneeweis, the specimen eventually found its way to Yatskievych's attention. The senior author has been collaborating with L. Turner Collins (Evangel University) and Alison Colwell (U.S. National Park Service) on taxonomic studies and a floristic treatment of the holoparasitic genera of Orobanchaceae for the Flora of North America Project. The present study is an extension of that research.

It quickly became clear that regardless of its familial placement the original specimen represented an undescribed taxon. However, the material available at the start of the research was insufficient to allow a detailed morphological analysis without doing significant damage to the only specimen, and the lack of the basal portion of the original plant precluded a determination of whether the taxon had a parasitic or mycotrophic habit. As a young graduate student at the Universidad Nacional Autónoma de México (UNAM), the junior author accompanied Wayt Thomas on his 1985 botanical expedition and has continued to pursue floristic studies in the mountains of Guerrero. His experience with the flora and geography of the region gave hope that living material of this unusual plant might be rediscovered in the wild for further study.

Following unsuccessful searches for additional specimens in pertinent herbaria in the United States and Mexico, fieldwork was conducted in the region of the historical collection in Guerrero, Mexico, during June 2006 and July 2007 to locate and document plants in flower and fruit. Descriptions of the sites were compiled, including lists of the most significant components of the vegetation. Excavations were made to confirm the identity of the hosts (and to document the below-ground portions of the parasites), but because of the relatively small numbers of parasites present, only one host root was excised and collected. Both in situ and excavated material of the parasite and 
host were documented by digital photography and voucher specimens.

Pollen samples were mounted in glycerol for examination by light microscopy. Pollen samples for scanning electron microscopy (SEM) were acetolyzed for 8 minutes at $90^{\circ} \mathrm{C}$ using standard techniques (Erdtman, 1960), then dehydrated in an ethanol series and critical point-dried. Both pollen and seeds (the latter air-dried, unpretreated) were sputter-coated with gold-palladium and viewed on a Hitachi S$2600 \mathrm{H}$ scanning electron microscope (Hitachi, Tokyo, Japan). Leaf surfaces (to check for stomates) were viewed directly under a compound microscope from epidermal peels of liquid-fixed material and also from dried material using the cellulose acetate cast technique of Payne (1968).

Eremitilla mexicana Yatskievych \& J. L. Contreras, gen. et sp. nov. TYPE: Mexico. Guerrero: Mpo. Gral. de Heliodoro de Castillo, $91 \mathrm{rd}$. km W of turnoff of Mexico Hwy. 95 Libre ( $\mathrm{N}$ of Zumpango del Río) \& $2.8 \mathrm{rd}$. km W of village of Tiquimil on dirt rd. heading $\mathrm{W}$ across the Sierra Madre del Sur to Puerto de Gallo, in rocky, steep-walled ravine with small permanent stream crossing rd., $17^{\circ} 31^{\prime} 27.1^{\prime \prime} \mathrm{N}, 99^{\circ} 57^{\prime} 01.3^{\prime \prime} \mathrm{W}, 1955 \mathrm{~m}, 12$ June 2006, G. Yatskievych \& J. L. Contreras J. 06-43 (holotype, MEXU; isotype, MO). Figures 1-3.

Genus novum et species nova, solitaria apud species Orobanchacearum ovariis valde quinqueangulosis, verrucosis, unilocularibus, placentis quinque parietalibus.

Perennial root parasites, achlorophyllous; not producing roots, forming amorphous, swollen, somewhat flattened vegetative bodies laterally along host roots; these bearing current year's stems and black, senescent bases of previous year's stems; stems solitary or in clusters of 2 to several from each vegetative body, $15-45 \mathrm{~cm}$, unbranched, succulent, geniculate basally, where 6-12 mm diam., ascending irregularly to at or just above the soil surface, where 16-25 mm diam., \pm cylindrical (with irregularly thinner and thicker portions), yellow externally and internally, quickly oxidizing to brown when damaged. Leaves squamiform, densely spirally imbricate, those near the stem base $4-6 \times 5-8 \mathrm{~mm}$, broadly oblong to depressed-ovate, rounded to broadly angled at the tip; grading quickly into those of the main stem, these 10$22 \times 7-14 \mathrm{~mm}$, angled to a bluntly or sharply pointed tip; all leaves glabrous, finely longitudinally striate, with erose margins, the basalmost dark brown, the main cauline leaves yellow, but those in a distal band $1.5-6.5 \mathrm{~cm}$ somewhat sclerified, blackish, shiny. Inflorescences solitary, stout, terminal spikes, hemispheric to ovoid, the flowers densely spirally imbri- cate; bract 1 per flower, $21-28 \times 14-18 \mathrm{~mm}$, ovate to elliptic above a short, broad, stalklike base, the laminar portion somewhat concave (cupped around the flower), angled or slightly acuminate to a usually sharply pointed tip, the margins strongly erose, adaxially glabrous and reddish brown to reddish purple above the yellow base, abaxially densely vesicular-hairy (described under corolla) and blackened toward the tip, sometimes with the thinner margins brownish yellow; bracteoles usually present, usually 2 , \pm aligned with lateral sepals, 14-21 $\times 7-$ $12 \mathrm{~mm}$, narrowly elliptic to narrowly rhombic above a broad stalklike base, curved or bent medially, otherwise similar to the bracts. Calyces \pm actinomorphic, of (4) 5 sepals, these 18-25 × 9-15 mm, attached separately on the corolla tube near its base, persistent, the stalklike proximal portion slightly shorter than to about as long as the laminar portion, this ovate, concave and curved or bent medially (cupped around and loosely appressed to the corolla), angled to a bluntly or sharply pointed tip, the margins strongly erose, reddish brown to reddish purple above the yellow to pale yellow base, the thinner margins brownish yellow, adaxially glabrous, abaxially densely vesicular-hairy (described under corolla); corolla aestivation cochleate-imbricate (the upper corolla lobe exterior in the bud); corollas zygomorphic, 4lobed (by almost complete fusion of the 2 upper lobes of a 5-merous corolla), overall 24-28 mm and somewhat arcuate, persistent and becoming papery at fruiting; the tube $10-13 \mathrm{~mm}$ long and wide, glabrous, mostly cream-colored to pale yellow, abruptly constricted distally on the ventral side above the ovary, reexpanded to $14-17 \mathrm{~mm}$ diam. in the throat (here defined as the expanded, tubular portion above the constriction and below the lobes), this 2$4 \mathrm{~mm}$ long, the throat and lobes mostly dark red externally in proximal portion, grading into reddish brown distally, densely pubescent externally with dull yellow to yellowish orange, vesicular hairs $0.3-$ $0.5 \mathrm{~mm}$, small groups of these sometimes coherent basally into short linear clusters; the lobes 10-13 mm, slightly overlapping laterally at anthesis, strongly erose and yellowish-hyaline along the margins, the upper lobe twice as wide as the others, shallowly cucullate, very broadly oblong, shallowly notched along the otherwise \pm truncate tip, the lateral lobes and lower lobe depressed-ovate to broadly oblongovate, shallowly concave (appearing slightly incurved); stamens 4, not exserted, the filaments free, inserted at the ovary base, 14-18 mm, equal in length or those of the anterior pair slightly longer than those of the posterior pair, relatively stout, not flattened, glabrous, white to cream-colored, ascending along the sinuses of the ovary, curved and somewhat connivent 

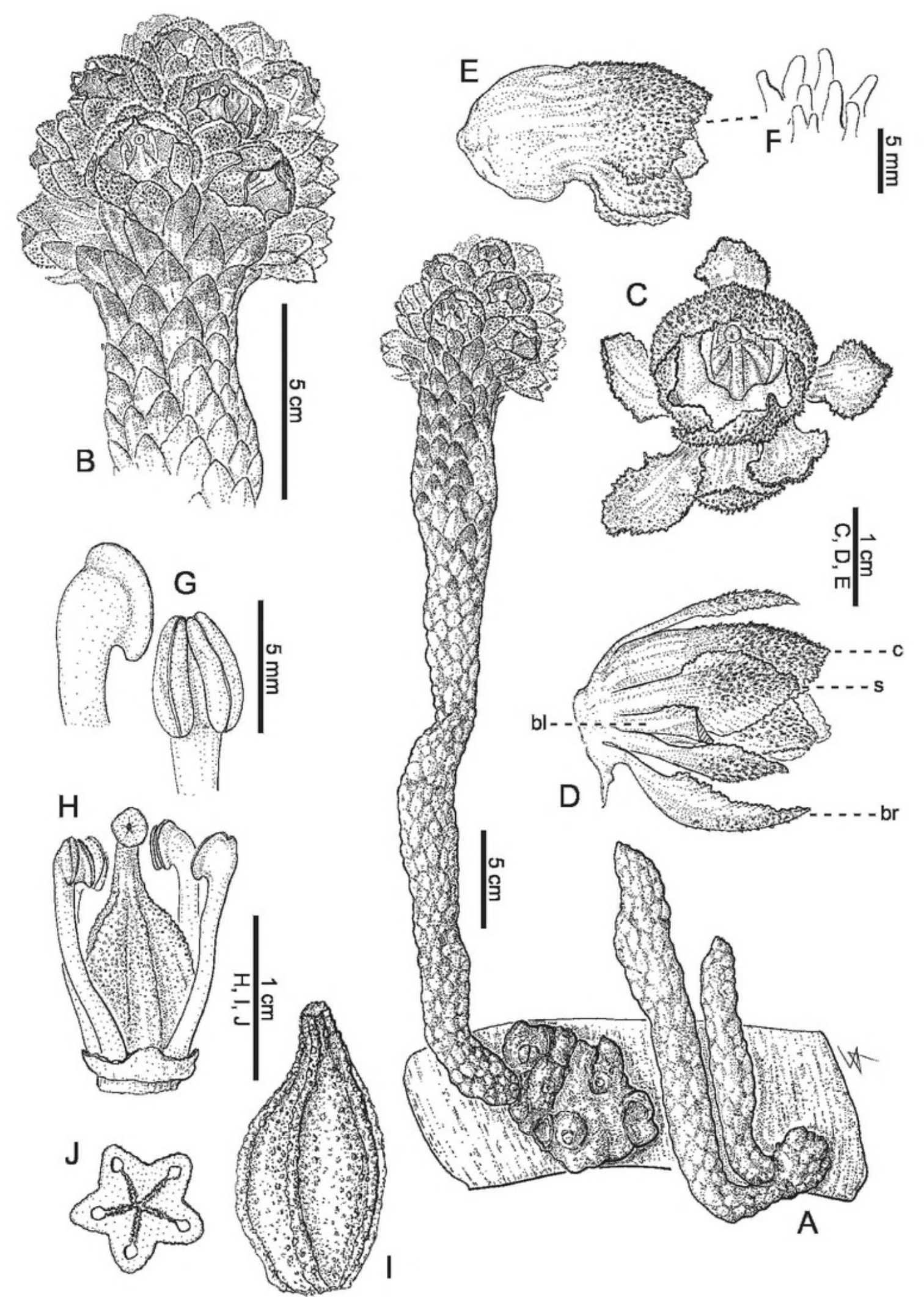

Figure 1. Eremitilla mexicana Yatskievych \& J. L. Contreras. -A. Habit, including portion of host root. -B. Inflorescence and upper stem. - C. Flower, frontal view, with sepals and bract spread to facilitate observation of corolla. -D. Flower, lateral view; bl, bracteole (distal portion removed to avoid obscuring perianth); br, bract; c, corolla; s, sepal. -E. Corolla, lateral view. -F. Vesicular trichomes. - G. Stamens, lateral and ventral view of anthers and filament tips. - H. Flower with bract, bracteoles, and perianth removed to expose stamens and pistil. - I. Fruit. - J. Cross section of ovary showing placentae. A-H, J, drawn from Yatskievych \& Contreras J. 06-43 (MEXU, MO); I, drawn from Yatshievych, Olson \& Trejo H. 07-106 (MEXU, MO, NY). 

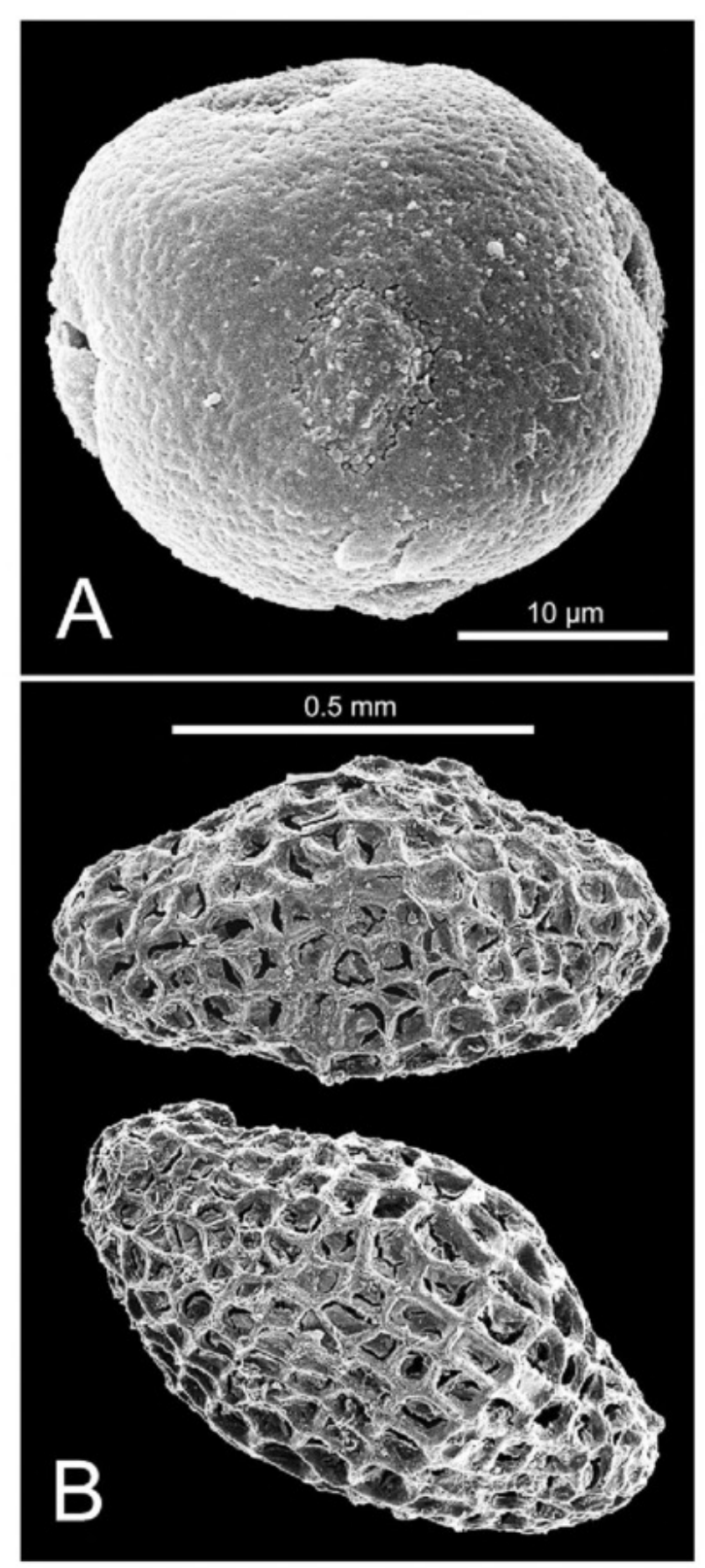

Figure 2. Pollen grain and seeds of Eremitilla mexicana Yatskievych \& J. L. Contreras. -A. Pantoporate pollen grain, with six equidistant pores (Yatskievych \& Contreras J. 06-45). - B. Seeds, showing the deeply reticulate outer surface (Yatskievych et al. 07-106).

distally under the upper corolla lobe, expanded abruptly apically, the anthers attached dorsally, but appearing partially embedded in the expanded tip, $4.0-4.9 \mathrm{~mm}$ long, glabrous, pale yellow grading to yellow, dithecate, the thecae \pm parallel, narrowly oblong-reniform, each dehiscing on the ventral side by a longitudinal slit (the slits ventral rather than lateral), often with a narrow line of dark reddish purple along the slit; pollen sticky, the grains shed as monads or irregularly coherent, globose or nearly so, yellow, 26$30 \mu \mathrm{m}$ diam. pantoporate with 4 equatorial and 2 polar, equidistant pores, the exine surface foveolate and slightly rugulate with scattered microperforations; pistil 1, apparently of 5 fused carpels, the ovary ovoid, 12-15 mm long, strongly 5-angled with slightly concave sinuses and rounded ribs (appearing fluted), the surface muricate, otherwise glabrous, pale yellow, short-tapered apically into the solitary style, this 5$8 \mathrm{~mm}$ long, not exserted, strongly arcuate under the upper corolla lobe, hollow, \pm persistent (the apex sometimes breaking off irregularly) at fruiting, white proximally, grading abruptly into dark red or dark reddish purple distally, the stigma 1 , discoid-crateriform, 2.0-2.5 mm diam., \pm circular (sometimes slightly irregular or very slightly 5 -lobed), dull yellow, with a minute, \pm 5 -lobed, central pore; locule 1 , with 5 massive placentae intrusive from the sinus portions of the ovary wall, these irregularly 2 - or 3-lobed, the ovules numerous, minute, white. Fruits capsular, but essentially indehiscent (decaying in situ), overall 16$20 \mathrm{~mm}$, the body ovoid, tapered to an irregular, short beak, plump (not concave between the ribs), strongly 5-ribbed, the surface muricate, reddish-tinged to reddish brown at maturity, becoming dark brown to black with age; seeds numerous, $0.4-0.9 \mathrm{~mm}$, irregularly ellipsoid to obovoid, reddish brown with dark brown ridges, the surface appearing reticulate (by enlarged cells of outer testa whose outer walls rupture at maturity), the pits irregularly polygonal.

Phenology. Eremitilla mexicana flowers during June and July.

Etymology. From the Latin, Eremitilla mexicana translates literally to "little hermit of Mexico," an allusion to the plant's secretive habit and limited occurrence.

Distribution. Based on current knowledge, this species is endemic to the inland slope of the Sierra Madre del Sur in Guerrero, Mexico, at elevations of 1800-2000 m.

Habitat. The mostly unpaved road along the inland side of the Sierra Madre del Sur in the Mexican state of Guerrero climbs gradually from ca. $500 \mathrm{~m}$ near its eastern terminus at the junction with Federal Highway 95 north of Chilpancingo to a maximum elevation of ca. $3200 \mathrm{~m}$ to the east of Puerto Gallo. The linear distance between these points is only about 75 air $\mathrm{km}$, but the road requires more than $140 \mathrm{~km}$ to span this distance. Along the route, it passes through several vegetation zones. The lowest elevations are a dry, deciduous woodland dominated by various Fabaceae and Cactaceae (a matrix of matorral xerófilo and bosque tropical caducifolio, 


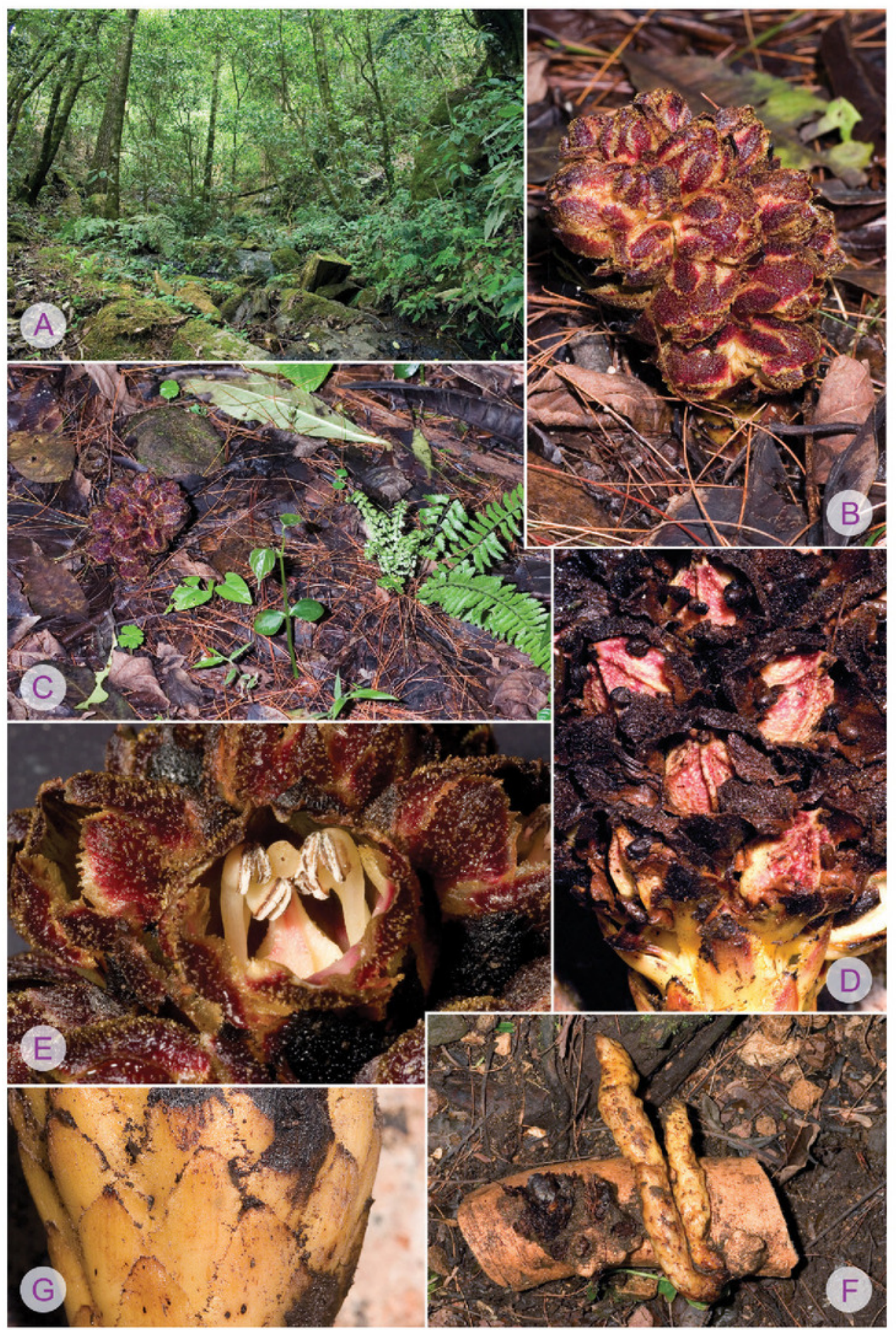

Figure 3. Eremitilla mexicana Yatskievych \& J. L. Contreras. -A. Type locality, bottom of mesic ravine. -B. Inflorescence. —C. Forest floor, showing inflorescence in situ (to left of center). - D. Detail of infructescence. -E. Close-up of flowers, showing orientation of perianth, androecium, and gynoecium. - F. Section of host root with two separate infections; note that current year's flowering stems have been removed from left-hand infection (see interpretive drawing in Fig. 1A). -G. Stem detail, showing appressed squamiform leaves. (B, C, E-G from Yatskievych \& Contreras J. 06-43 [type], D from Yatskievych et al. 07-106.) 
sensu Rzedowski, 1981). The highest elevations support a mixed conifer-evergreen hardwood montane forest dominated by Pinus L., Abies Miller, Quercus L., and various other hardwoods, with many Ericaceae in the understory and a thick layer of mosses on the ground. Substrates are mostly of igneous and volcanic origin, except for an unusual area of weathered, dissected limestone near the village of Yextla.

Despite extensive searches in suitable habitat during two field seasons, only two populations of Eremitilla were discovered, each with fewer than 20 inflorescences. The apparent site of the initial 1985 discovery had suffered the effects of a fire that killed most of the primary woody vegetation and was in an early stage of recovery; no plants of the new taxon were present. Conversations with local villagers lead us to believe that additional plants exist in more remote parts of the area, but the rugged terrain and lack of roads and trails precluded further searches during the time available for our work.

The two sites where we were able to study the new taxon are about $1 \mathrm{~km}$ apart and about $90 \mathrm{~km}$ from the eastern end of the road. At this intermediate elevation of ca. 1800-2000 m, the main vegetation consists of pine-oak forests. Dissecting this landscape is a network of steep-walled, rocky ravines, most of which have small springs feeding into streams that are the primary sources of water for local villages and farms. The steep walls and permanent flow in these headwater drainages provide a permanently moist, humid microenvironment that supports a diversity of tropical hardwoods (some of these trees to more than $20 \mathrm{~m}$ tall) and herbaceous plants (Fig. 3A). The transition between this restricted habitat and the surrounding seasonally dry forests usually is very abrupt.

Woody plants recorded in the ravines that harbor the new taxon include one or more species in the following genera: Alnus Miller (Betulaceae), Ardisia Swartz (Myrsinaceae), Canavalia DC. (Fabaceae), Clethra L. (Clethraceae), Conostegia D. Don (Melastomaceae), Croton L. (Euphorbiaceae), Eugenia L. (Myrtaceae), Fuchsia L. (Onagraceae), Hedyosmum Swartz (Chloranthaceae), Miconia Ruiz \& Pavón (Melastomaceae), Oreopanax Decaisne \& Planchon (Araliaceae), Pinus (Pinaceae), Pithecellobium Martius (Fabaceae), Quercus (Fagaceae), Rapanea Aublet (Myrsinaceae), Salvia L. (Lamiaceae), Smilax L. (Smilacaceae), and Ternstroemia Mutis ex L. f. (Pentaphylaceae). Herbaceous genera include: Adiantum L. (Pteridaceae), Amicia Kunth (Fabaceae), Aneilema R. Brown (Commelinaceae), Asplenium L. (Aspleniaceae), Begonia L. (Begoniaceae), Botrychium Swartz (Ophioglossaceae), Dioscorea L. (Dioscoreaceae), Gonolobus Michaux (Apocynaceae),
Hydrocotyle L. (Araliaceae), Matelea Aublet (Apocynaceae), Pteris L. (Pteridaceae), Thelypteris Schmidel (Thelypteridaceae), and Woodwardia Smith (Blechnaceae).

Both of the localities from which Eremitilla was documented have sustained minor impacts. These include the construction of the dirt road (and associated bank stabilization) across the ravine, diversion by pipe of a portion of the water in the streams, and selective timber removal. Many of the other drainages along the road have sustained more significant impacts from timber harvesting, fire, livestock, and colonization by early-successional plant species, such as Pteridium Gleditsch ex Scopoli and Rubus L., including the presumed site of the original discovery of the parasite.

IUCN Red List category. As an apparently localized endemic, Eremitilla mexicana may best be considered a relictual taxon. Taxonomically isolated within the Orobanchaceae, the species probably is a relatively old one that may once have been more abundant when habitat suitable for its host plant was more continuous. Given the sporadic occurrence in the region of headwater drainages with suitable microhabitats for the host species, the parasite is likely dispersal-limited. Under such a scenario, $E$. mexicana naturally and gradually may be approaching extinction. The inland slope of the Sierra Madre del Sur in Guerrero still has abundant primary forests, but long-term logging operations in the region inevitably are taking their toll. The practice of burning cut-over areas to prevent recruitment of woody species and the conversion of many logged areas into pasturage or orchards creates additional impacts to the mesic ravines by increasing local erosion and potentially causing changes in the surface hydrology. Plant species that have a limited ecological niche are among those most vulnerable to decline as a result of habitat degradation. The observation that E. mexicana only flowers when attached to large lateral roots of mature trees further narrows the potential habitat for the species. It is not known whether the soil seed bank for the parasite is especially long-lived.

According to Todzia (1988), Hedyosmum mexicanum C. Cordemoy is relatively widespread, with a range from central Mexico to Costa Rica, and occurs variously at elevations of $700-3200 \mathrm{~m}$. It is the only species of Hedyosmum to occur in Mexico and, aside from some Caribbean species, has the most northerly distribution in the genus. Given the relatively broad distribution of $H$. mexicanum in North and Central America and its relatively great elevational range, it is surprising that Eremitilla has not been discovered growing in other places. Perhaps the present publi- 
cation will alert collectors to be on the lookout for this unusual plant and it will be discovered elsewhere in Mexico or Central America. Certainly, it should be searched for along the inland side of the Sierra Madre del Sur in other Mexican states from Jalisco to Chiapas. The parasite is relatively easily overlooked by collectors, flowers above ground only during part of the year, and blends in with the leaf litter, thus the species probably is best considered Data Deficient (DD) according to IUCN Red List criteria (IUCN, 2001). However, based on the current data alone, the species would have to be classified at least as Vulnerable (VU) in that system (IUCN, 2001).

Taxonomic relationships. The parasitic habit of Eremitilla mexicana precludes its classification among the mycoheterotrophic members of the Ericaceae subfam. Monotropoideae. The production of four loosely connivent stamens (vs. six to 12) per flower (Figs. 1G, H, 3E) and the small seeds with an enlarged outer testa layer (Fig. 2B) (vs. minute seeds with a very thin testa one cell layer thick) provide morphological support for this interpretation. Flowers of Eremitilla also lack other characters that are common (but not ubiquitous) among the monotropoid ericads (Cronquist, 1981), such as actinomorphic corollas, production of well-developed nectaries, axile placentation, short styles, and resupinate anthers. However, it is easy to understand why the late Larry Heckard would have annotated the original specimen as possibly belonging to this group, given the distinct sepals and strongly 5-angled ovary (Fig. 1H, J).

Placement of Eremitilla in the Orobanchaceae is most parsimonious. Root parasitism is a synapomorphy above the basal branch in the family and a number of genera produce a well-defined vegetative body from which the flowering stems arise (Figs. 1A, $3 \mathrm{~F})$. The flowers of Eremitilla are similar to those of most Orobanchaceae in their basically 5-merous perianth with a zygomorphic corolla (Figs. 1C, 3E), as well as an androecium of four stamens (Figs. 1H, 3E) and an ovary with parietal placentation (Fig. 1J). The inflorescences of Eremitilla bear a strong resemblance to those of some genera of Orobanchaceae, both in terms of their organization and in the production of bracts and bracteoles. The seeds of Eremitilla also are of a type common in the Orobanchaceae (the so-called deeply reticulate type of Musselman \& Mann, 1976) in having the testa with an outer layer of enlarged polygonal cells whose outer walls tend to rupture as the seed reaches maturity, leaving a highly sculptured series of reticulate ridges with deep intervening pits of characteristic morphology (Fig. 2B).

However, Eremitilla possesses several autapomorphic morphological characters that are discordant in the Orobanchaceae and require adjustments to the morphological circumscription of the family. Foremost among these, the 5-ribbed ovary and fruit (Figs. 1H, I, 3D) are not known in the family, which normally has a more or less terete gynoecial cross section with at most slight ridging along the septa. Species of Orobanchaceae have a 2(3)-carpellate pistil that has two(three) or four (by deep lobing), usually intrusive, parietal placentae (Cronquist, 1981), whereas in Eremitilla there are five intrusive placentae presumably derived from five carpels (Fig. 1J). The alternative hypothesis that the ovary of Eremitilla arose through modification (by lobing of intrusive placentae) of a 2-carpellate pistil is plausible, but would require a much more complicated series of structural and developmental changes to have occurred. The 2carpellate character state in most Orobanchaceae is correlated with the production of 2- or 4-lobed stigmas or of more or less unlobed, crateriform stigmas, whereas the crateriform stigmas in Eremitilla have a more or less 5-lobed central pore (Fig. 1H).

The stamens of Eremitilla also are unusual in the Orobanchaceae in having the filaments inserted at the base of the ovary and not epipetalous within the corolla tube (Fig. 1H). Anther morphology in the Orobanchaceae is variable, with various shapes and sometimes the production of appendages or spurs, but the condition of having the anthers partially embedded in the expanded filament apex (Figs. 1G, H, 3E) is not known elsewhere in the family. Pantoporate pollen (Fig. 2A), as is found in Eremitilla, occurs sporadically in a number of distantly related angiosperm families, but is unknown in Orobanchaceae and within the order Lamiales is characteristic only of Plantago L. and related genera (Plantaginaceae). Minkin and Eshbaugh (1989) found that pollen grains of Boschniakia C. A. Meyer ex Bongard, Conopholis Wallroth, Epifagus Nuttall, and Orobanche L. sect. Gymnocaulis Nuttall are tricolpate with various surface sculpturing. The foveolate exine surface (Fig. 2A) of Eremitilla is not unusual in the Orobanchaceae (Type III of Minkin \& Eshbaugh, 1989).

In addition, the relatively stout, vesicular trichomes of Eremitilla (Figs. 1F, 3E) differ from the pubescence types present in other Orobanchaceae, which consist of slender, short trichomes that often are gland-tipped. Vegetatively, the lack of stomates on the scale leaves separates Eremitilla from most other genera of Orobanchaceae (Linsbauer \& Ziegenspeck, 1943).

If one accepts Eremitilla as an unusual member of the Orobanchaceae, then the construction of hypotheses about relationships with other genera in that family is difficult. Previous molecular studies using the plastid markers matK (Young et al., 1999; Young 
\& dePamphlis, 2005), rbcL (Wolfe \& dePamphlis, 1998; Young \& dePamphlis, 2005), and rps2 (dePamphlis et al., 1997; Young et al., 1999; Young \& dePamphlis, 2005) have shown that holoparasitism has evolved multiple times within the family, but did not provide sufficient resolution to support particular relationships within the group that includes the New World holoparasitic genera. Phylogenetic surveys of the family using the nuclear markers ITS (Wolfe et al., 2005) and PHYA (Bennett \& Mathews, 2006) gave better resolution within this group, disagreeing in some details but generally supporting a division between Orobanche and the other holoparasitic American genera (Boschniakia [including Kopsiopsis (Beck) Beck], Conopholis, and Epifagus). Samples of Eremitilla tissue dried in silica have been sent for analysis to Gerald Schneeweis (University of Vienna) and to Sarah Mathews (Harvard University) for molecular analysis. Preliminary results from analyses of ITS and rps2 sequences placed Eremitilla $a$ at the base of a lineage that includes the other North American holoparasitic genera, but have not been successful in adding resolution concerning intergeneric relationships within the group (Mathews et al., 2008). As with morphological characters, Eremitilla appears to possess many autapomorphies in the molecular data sets, leading to its placement on a relatively long branch. Further studies are under way, using additional markers.

Among the holoparasitic genera native in the New World, production of some sort of vegetative body is common, except in the American representatives of Orobanche, only a few of which produce such structures (e.g., O. bulbosa Beck). However, among the genera producing a discrete vegetative body, the relative size and shape of this structure differ between species. The other North American genera all flower while attached to roots that are much more slender than those infected by Eremitilla, thus there may be architectural constraints on the vegetative body in Eremitilla that result in the development of a more flattened, rather than globose, vegetative organ (Figs 1A, 3F).

The corollas of Eremitilla have much broader tubes and throats than in any of the other ca. 20 New World species of holoparasitic Orobanchaceae (Figs. 1C, $3 \mathrm{E})$. Genera such as Boschniakia and Conopholis share with Eremitilla the character of the upper two corolla lobes more or less fused into a single, often emarginate unit (Figs. 1C, 3E) that frequently is incurved or slightly hooded (vs. usually spreading in Orobanche s.l.). Also, as in Eremitilla, the corollas in these genera tend to be overall more shallowly lobed (Fig. 1D, E) than in North American Orobanche. The corolla tube in Boschniakia and Kopsiopsis is narrowed and curved above the ovary, similar to the condition of the corollas in Eremitilla (Fig. 1E), which, however, has a broader throat than in the other genera. However, the calyces in this group of genera are all strongly gamosepalous, whereas in the new genus the sepals are not coherent basally (Fig. 1D). The calyces in Orobanche, on the other hand, usually are divided nearly to the base.

The following key is artificial, rather than synoptic, given the paucity of identifiable morphological synapomorphies that would contribute phylogenetic structure to the clade. The generic classification remains a work in progress, with new data still emerging to suggest that the New World subgenera of Orobanche should be classified as segregate genera (Gerald Schneeweis, pers. comm.) and with generic limits to circumscribe monophyletic groups among the remainder of the American genera still tentative.

Key to the Genera of Holoparasitic Orobanchaceae Native in the New World

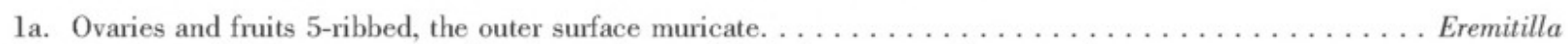

1b. Ovaries and fruits terete or slightly flattened, not ribbed, the outer surface smooth.

2a. Calyces deeply 5-lobed; corollas with the upper lip usually moderately to strongly spreading to recurved at anthesis (flowers all chasmogamous).

3a. Pedicels $4-25 \mathrm{~cm}$, mostly as long as or longer than the flowering stems; flowers 1 to 10 per flowering stem, each with a bract but lacking bracteoles . . . . . . . . . . . . . . Orobanche sect. Gymnocaulis

$3 \mathrm{~b}$. Pedicels absent or to $3(4) \mathrm{cm}$, when present shorter than the flowering stems; flowers usually numerous, each with a bract and 1 or 2 bracteoles .......... Orobanche sect. Nothaphyllon (A. Gray) Heckard

$2 \mathrm{~b}$. Calyces entire along the rim or more commonly with 1 to 5 teeth or lobes, these generally shorter than to about as long as the tube (the tube split longitudinally along one side in Conopholis and sometimes with a single long tooth in Kopsiopsis); corollas with the upper lip slightly spreading (sometimes in Kopsiopsis) or more commonly straight, slightly incurved, or cucullate at anthesis (except in cleistogamous flowers).

4a. Flowering stems usually well-branched above the base, slender, the flowers widely spaced along the branches; proximal flowers cleistogamous; calyces actinomorphic or nearly so . . . . . . . . Epifagus

4b. Flowering stems usually unbranched, stout, the flowers densely spaced along the axis; cleistogamous flowers absent; calyces zygomorphic.

5a. Calyces with the tube split deeply longitudinally along the anterior side; flowering stems usually few to several in a dense cluster from the vegetative body; seeds with the outer surface nearly smooth or with a fine network of irregular, sinuous grooves, often appearing roughened or finely and irregularly reticulate-ridged in patches $\ldots \ldots \ldots \ldots \ldots \ldots \ldots \ldots \ldots \ldots \ldots \ldots$. $\ldots \ldots \ldots$. $\ldots \ldots \ldots$ 
5b. Calyces often somewhat zygomorphic, but the tube not split longitudinally; flowering stems usually solitary from the vegetative body; seeds with the outer surface prominently reticulate-ridged.

6a. Corollas with the lower lip shorter than the upper lip or sometimes absent or nearly so, the lobes (when present) to ca. $1 \mathrm{~mm}$ long, the upper lip \pm incurved to somewhat cucullate; bracteoles absent; anthers strongly exserted; fruits 2-valved; seeds oblong-cylindric; vegetative body with

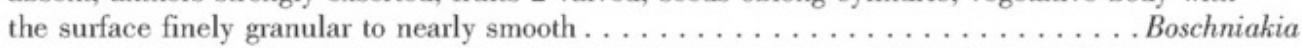

6b. Corollas with the lower lip about as long as the upper lip, the lobes $3-5 \mathrm{~mm}$ long, the upper lip straight, not cucullate; bracteoles usually present; anthers included or barely exserted; tuft of hair at base of stamen; fruits either 3- or 4-valved; seeds broadly ovoid; vegetative body with the

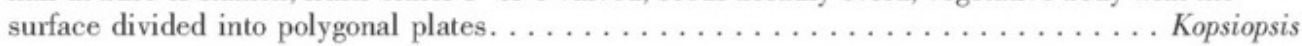

Life history. Eremitilla mexicana is a perennial taxon. Presently, nothing is known about seed germination, attachment to the host, or haustorial development in Eremitilla. In most other holoparasitic Orobanchaceae, the seeds require host root tips nearby or even in direct contact to promote embryo development and seed germination, and a chemical stimulus (host root exudate) is thought to be necessary to stimulate maturation of the parasite embryo (Kuijt, 1969; Olsen \& Olsen, 1979; Baird \& Riopel, 1986a, b). During an unspecified period of time after germination (probably several years, based on its woody texture), the subterranean parasite develops an amorphous, somewhat flattened, broadly adherent, vegetative body on the exterior, lateral surface of the more or less horizontal host root (Figs. 1A, 3F). Analogous growths of various shapes, sizes, and textures are produced in some other genera of Orobanchaceae, and have variously been described as tuberous, bulbous, or cormlike, but none of these terms accurately describes the flattened, relatively hardened structures produced in Eremitilla. In some other genera of Orobanchaceae, such structures have been called tubercles (Kuijt, 1969; Heide-Jørgensen, 2008), although this term also does not appear to apply accurately to the vegetative body in Eremitilla. Anatomical studies have not been performed, but hand-sectioning indicates that this vegetative body includes at least some anomalous growth of host tissue in its interior. There was no indication of any development of roots by the parasite; that is, it is unlikely that the parasite spreads vegetatively to form new infections along a given host root, but that adjacent parasites on the same root apparently represent independent infections. We observed one to four vertical stems of the parasite at different stages of development from a given infection site, as well as the blackened remains (Fig. 3F) of stems from the previous growing season (and in a few cases scars that may represent the emergence points of stems from even earlier years). The elongating stems are sharply pointed at the tip and eventually extend $15-45 \mathrm{~cm}$ to reach the soil surface. Because of rocks in the soil, frequently the stems of Eremitilla ascend irregularly, with kinks where they bend abruptly around obstruc- tions (Fig. 1A). Toward each stem tip is a zone of dark, sclerotic squamiform leaves (Fig. 1A, B) that presumably functions to protect the immature inflorescence, which shows no sign of differentiation in the material observed until the stem has nearly reached the surface.

The inflorescences of Eremitilla are not stalked or only short-stalked above the ground and are orangish brown in overall color, darkening to brown after flowering as the fruits develop and eventually blackening with age (Fig. 3B, C). They blend in very well with the leaf litter. No insects were observed visiting flowering individuals in situ, but excavated stems were visited by small flies, small bees, and a small butterfly on the open roadbank prior to pressing. The stigma is positioned at about the same level but often slightly in front of the anthers of the anterior pair of stamens, which dehisce more or less inward toward the stigma (Figs. 1H, 3E). There is thus the potential of pollen transfer from the adjacent anthers to the stigma, suggesting that the species is at least facultatively inbreeding. There was no evidence of cleistogamous flower production. In the infructescences that we observed, nearly every flower had produced a fruit. Fruit development and ripening require a month or more after flowering (inferred from our field studies). The capsular fruits do not dehisce at maturity, but remain intact within the persistent perianth until ruptured by eventual decay of the infructescence. We observed black, collapsed remains of previous years' infructescences in the field with well-formed seeds still present. In addition to soilborne fungi and bacteria, various insect larvae that tunnel through the stems contribute to the decomposition of the plants.

Seed dispersal in Eremitilla is likely to be accomplished by a combination of factors, mainly gravity and water. The bottoms of the steep-walled ravines where the plants grow generally are not subjected to regular wind, especially at ground level. Ants are another possible dispersal agent, as undetermined ants were observed in and around some of the decaying infructescences. As in many other species of Orobanchaceae, the outer layer of the seed coat consists of a layer of enlarged polygonal cells 
whose outer facets rupture with age, creating a deeply sculptured surface (Fig. 2B). Olsen and Olsen (1980) suggested that water and hydrostatic charge were the principal agents responsible for dispersal on the morphologically similar seeds of Boschniakia hookeri Walpers, as well as their transport into the soil, but could not rule out zoochory as a contributing factor.

Host association. Excavation of the stems of the parasite is difficult in the rocky soils of the habitat. We were surprised to find the attachment to the host root to be relatively deep (to $45 \mathrm{~cm}$ ), given that the developing flowering stems must push through the rocky soil to reach the surface. Our field studies indicate that the only host plant of Eremitilla mexicana is the tree species Hedyosmum mexicanum (Chloranthaceae). The parasites were attached exclusively to large $(6-10 \mathrm{~cm}$ or more diam.) lateral roots (Figs. 1A, 3F) of mature trees and formed a series of individual infections spaced 10 or more $\mathrm{cm}$ apart along the lateral surface of the root. In the ravines that we visited, $H$. mexicanum is a slender-trunked canopy tree to ca. $25 \mathrm{~m}$ tall with expanded, slightly buttressed bases and gray, finely roughened bark. As with most Chloranthaceae, the plants are resinous, with a distinctive aromatic odor when bruised or otherwise damaged, which facilitates identification of even the roots. Within the region, it is among the first tree species to colonize following clear-cutting or fires and also is present in runoff depressions along the road. However, even though the density of Hedyosmum is much greater at such disturbed sites than in the mature primary vegetation of the less impacted ravines, no incidence of parasitism was noted in these younger stands of trees. Parasites were observed attached only to large mature individuals of the host. This is the first report of a vascular plant parasitic on Hedyosmum.

Paratypes. MEXICO. Guerrero: Mpo. Gral. de Heliodoro de Castillo, $50.5 \mathrm{~km}$ ENE of Puerto de Gallo, 9 June 1985, W. Thomas \& J. L. Contreras J. 3762 (FCME, NY); $91 \mathrm{rd}$. km W of turnoff of Mexico Hwy. 95 Libre \& 2.8 rd. $\mathrm{km} \mathrm{W}$ of village of Tiquimil on dirt rd. to Puerto de Gallo, 24. July 2007, G. Yatskievych, M. Olson \& L. Trejo H. 07104 (topotype, MEXU, MO); $90 \mathrm{rd}$. km W of turnoff of Mexico Hwy. 95 Libre \& 1.9 rd. $\mathrm{km} \mathrm{W}$ of village of Tiquimil on dirt rd. to Puerto de Gallo, 13 June 2006, Yatskievych \& Contreras J. 06-45 (FCME, MO), 24 July 2007, Yatskievych, Olson \& Trejo H. 07-106 (MEXU, MO, NY).

Acknowledgments. We greatly appreciate Wayt Thomas's perseverance in seeking a determination for his original collection for over two decades and his kindness in discussing the situation with us. Thanks also are due to Gerald Schneeweis for his role in bringing the original specimen to the authors' attention. FNA co-authors Turner Collins and Alison Colwell provided insightful discussions and encouragement during the study, as did Peter Stevens and Roy Gereau of the Missouri Botanical Garden. Suggestions and corrections made by reviewers Dan Nickrent and Turner Collins, as well as the Novon editorial staff, greatly improved the manuscript. Gerald Gastony kindly assisted with the Latin diagnosis. Mark Olson and Laura Trejo Hernández of the MEXU herbarium and UNAM botanical institute provided logistical support for the 2007 fieldwork and excellent field assistance. We appreciate the meticulous skill of John Myers in preparing the plate of illustrations. Pollen samples initially were processed for us by Steven Manchester of the University of Florida. A second set of pollen samples, as well as seeds, were processed by University of Missouri-St. Louis doctoral student Sara FuentesSoriano, who also performed the scanning electron microscopy. The SEM work was conducted in the Research Center for Auditory and Visual Studies (funded by NIH grant P30 DC004665) of the Department of Otolaryngology at Washington University in St. Louis. Specimens were collected under permits issued to José Luis Contreras Jiménez and Mark Olson by CONACYT, the Mexican governmental agency responsible for the conservation of biodiversity. Portions of this research were supported financially by the Science and Conservation Division of the Missouri Botanical Garden.

\section{Literature Cited}

Baird, W. V. \& J. L. Riopel. 1986a. Life history studies of Conopholis americana (Orobanchaceae). Amer. Midl. Naturalist 116: 140-151.

— \& 1986b. The developmental anatomy of Conopholis americana (Orobanchaceae) seedlings and tubercles. Canad. J. Bot. 64: 710-717.

Bennett, J. R. \& S. Mathews. 2006. Phylogeny of the parasitic plant family Orobanchaceae inferred from Phytochrome A. Amer. J. Bot. 93: 1039-1051.

Cronquist, A. 1981. An Integrated System of Classification of Flowering Plants. Columbia University Press, New York.

dePamphlis, C. W., N. D. Young \& A. D. Wolfe. 1997. Evolution of plastid gene rps 2 in a lineage of hemiparasitic and holoparasitic plants: Many losses of photosynthesis and complex patterns of rate variation. Proc. Natl. Acad. Sci. U.S.A. 94: 7367-7372.

Erdtman, G. 1960. The acetolysis method, a revised description. Svensk Bot. Tidskr. 54: 561-564.

Heide-Jørgensen, H. S. 2008. Parasitic Flowering Plants. Koninklijke Brill, Leiden, The Netherlands.

IUCN. 2001. IUCN Red List Categories and Criteria, Version 3.1. Prepared by the IUCN Species Survival Commission. IUCN, Gland, Switzerland, and Cambridge, United Kingdom.

Kuijt, J. 1969. The Biology of Parasitic Flowering Plants. University of California Press, Berkeley. 
Linsbauer, K. \& H. Ziegenspeck. 1943. Das Vorkommen von Spaltöffnungen bei heterotrophen Blütenpflanzen im Lichte der Physiologie und Stammesgeschichte. Biol. Gen. 42: 511-565.

Mathews, S., G. M. Schneeweiss \& G. Yatskievych. 2008. Phylogenetic affinities of a new holoparasitic genus of Orobanchaceae endemic to Guerrero, Mexico, inferred from molecular data. Botany 2008 Conference, Vancouver, Canada [Abstract].

Minkin, J. P. \& W. H. Eshbaugh. 1989. Pollen morphology of the Orobanchaceae and rhinanthoid Scrophulariaceae. Grana 28: 1-18.

Musselman, L. J. \& W. F. Mann. 1976. A survey of surface characteristics of seeds of Scrophulariaceae and Orobanchaceae using scanning electron microcopy. Phytomorphology 26: 370-378.

Olsen, S. \& I. D. Olsen. 1979. Growth of host root establishes contact with parasitic angiosperm Boschniakia hookeri. Nature 279: 635-636.

$\&$. 1980. The seed of Boschniakia hookeri. Bot. Tidsskr. 75: 159-172.
Payne, W. W. 1968. The use of cellulose acetate film for the production of epidermal casts. Ward's Bull. 7(52): 6-7.

Rzedowski, J. 1981. Vegetación de México. Editorial Limusa, México D.F.

Todzia, C. A. 1988. Chloranthaceae: Hedyosmum. Fl. Neotrop. Monogr. 48: 1-139.

Wolfe, A. D. \& C. W. dePamphlis. 1998. The effect of relaxed functional constraints on the photosynthetic gene $r b c \mathrm{~L}$ in photosynthetic and nonphotosynthetic parasitic plants. Molec. Biol. Evol. 15: 1243-1258.

—, C. R. Randle, L. Liu \& K. E. Steiner. 2005. Phylogeny and biogeography of Orobanchaceae. Folia Geobot. 40: 115-134.

Young, N. D. \& C. W. dePamphlis. 2005. Rate variation in parasitic plants: Correlated and uncorrelated patterns among plastid genes of different function. BMC Evol. Biol. 5: 16. doi: 10.1186/1471-2148-5-16 [Online publication]. , K. E. Steiner \& C. W. dePamphlis. 1999. The evolution of parasitism in Scrophulariaceae/Orobanchaceae: Plastid gene sequences refute an evolutionary transition series. Ann. Missouri Bot. Gard. 86: 876-893. 


\section{$2 \mathrm{BHL}$ Biodiversity Heritage Library}

Yatskievych, George Alfred and Contreras-Jiménez, José-Luis. 2009. "A New Genus of Holoparasitic Orobanchaceae from Mexico." Novon a journal of botanical nomenclature from the Missouri Botanical Garden 19, 266-276.

View This Item Online: https://www.biodiversitylibrary.org/item/124658

Permalink: https://www.biodiversitylibrary.org/partpdf/121919

\section{Holding Institution}

Missouri Botanical Garden, Peter H. Raven Library

\section{Sponsored by}

Missouri Botanical Garden

\section{Copyright \& Reuse}

Copyright Status: Permission to digitize granted by rights holder Rights: https://www.biodiversitylibrary.org/permissions

This document was created from content at the Biodiversity Heritage Library, the world's largest open access digital library for biodiversity literature and archives. Visit BHL at https://www.biodiversitylibrary.org. 